Matthias Hofferberth*

\title{
"And of course our major contribution remains to run a decent business." Making sense of Shell's sense-making in Nigeria during the $1990 \mathrm{~s}$
}

\begin{abstract}
The intellectual engagement with multinational enterprises in International Relations has found a new home within the narratives of global governance and corporate social responsibility. Both narratives seem to agree that the role of business has changed as state capacities to provide governance assumingly have diminished and, based on broader social and political responsibilities, enterprises began to participate more actively in the provision of collective goods. Increased participation alone, however, does not reveal how corporate actors define and make sense of their responsibilities and their roles within global governance. In fact, focusing on corporate responsibilities and corporate governance contributions does not consider enterprises as actors in their own right who actively interpret and respond to changes in their normative environments. To fill this gap, the article proposes a framework that conceptualizes corporate agency as inherently social and creative. This framework, which can be applied to different contexts, is illustrated by reconstructing interpretative frames and self-understandings advanced by Shell in response to its crisis in Nigeria during the 1990s. Based on this reconstruction, Shell failed to develop and communicate a clear understanding of its social responsibilities, and its overall integration into global governance is likely to remain an ambiguous process in which uncertainty and indeterminacy prevail.
\end{abstract}

doi:10.1017/bap.2016.8

That captains of industry are creative artists of a sort, and that industry absorbs an undue share of the creative activity of the present time cannot be denied. To impute to the leaders of industry and commerce simply an acquisitive motive is not merely to lack insight into their conduct, but it is to lose the clew to bettering conditions.

John Dewey, Human Nature and Conduct, p. 146

\footnotetext{
*Corresponding author: Matthias Hofferberth, University of Texas at San Antonio, Department of Political Science and Geography, One UTSA Circle, San Antonio, TX 78249-0648, USA, e-mail: matthias.hofferberth@utsa.edu
} 


\section{Introduction}

Twenty-five years after Lorraine Eden's call to 'bring the firm back in,' multinational enterprises (MNEs) have become a well-established and popular research object in International Relations (IR). ${ }^{1}$ Assuming a more engaged and active role of business in larger political frameworks, MNEs today are prominently discussed in terms of their social and ethical responsibilities as well as in their relations to other public governance institutions. ${ }^{2}$ In these debates, consensus seems to emerge around the notion that accepting broader responsibilities and becoming more engaged in political matters is no longer only an option but rather the 'right thing to do' for business, both from an ethical as well as from an economic perspective. ${ }^{3}$ While in a narrow sense concerned with corporate motivations and agency, these discussions on the role and responsibilities of MNEs vis-à-vis society are oftentimes situated and framed in a broader global governance perspective focused on order, structure, and the provision of public goods. The proliferating literature on private authority and the ensuing debates on the role and responsibilities of corporate actors are a case in point, indicating that the engagement with MNEs is not only alive but has also found a new intellectual home in terms of CSR and global governance. ${ }^{4}$

Considering the limited attention MNEs received in IR during the 1980s and 1990s, their recent rediscovery is a notable feat, which provided valuable insights to the interdisciplinary discourse on enterprises and their role and responsibilities in global governance. However, given its focus on order and the provision of public goods, studying MNEs within a global governance framework at the same time privileges certain research questions and answers over others. ${ }^{5}$ As it stands,

1 Eden (1991). Following Dunning's (1971), 16, seminal definition, the article defines a multinational enterprise as "an enterprise which owns or controls producing facilities [...] in more than one country." While this definition is widely accepted, various terms exist to identify the phenomenon. I use the term 'enterprise' since "all multinationals are enterprises but not all are incorporated" (Eden (1991), 219). The addition of 'multinational' is intended to indicate that the operations of these enterprises cross but do not transcend state borders.

2 See Büthe (2010), and Levy and Prakash (2003).

3 See Scherer et al. (2006) for the ethical and Pies et al. (2009) for the economic reasoning.

4 Prominent examples of the thriving private authority and governance literature, among others, would include in chronological order Büthe and Mattli (2011); Ougaard and Leander (2010); Kobrin (2009); Mattli and Woods (2009); Pattberg (2005); Ruggie (2004); Hall and Biersteker (2002); Haufler (2001); and Cutler et al. (1999). For an overview of the literature see Schäferhoff et al. (2009) and May (2015) for an explicit focus on MNEs.

5 For two publications which advance this structural framework of global governance, see Karns et al. (2015), and Weiss and Wilkinson (2014). May (2015) provides a more balanced approach as he critically considers the governance of as well as the governance by MNEs. 
studying MNEs in global governance focuses on how participation affects their behavior and whether this provides better governance. While important, these questions do not exhaust the list of issues stemming from corporate actors becoming engaged in world politics and assuming new responsibilities. In particular, this article contents that there are three limitations inherent to such a perspective that constrain and impede insights on MNEs: (1) a functionalist bias that overstates the likelihood of MNEs becoming global governors, (2) a structural bias that focuses on governance provisions rather than corporate agency, and (3) a rational bias that reduces MNEs and their agency to rational profit maximization.

Spelled out in detail below, these limitations make it difficult if not impossible to consider MNEs as actors in their own right and discuss how they make sense of and respond to changes in their normative environments. ${ }^{6}$ Overall, in terms of their dispositions, we are in inclined to reduce MNEs to rational profit maximization and strategic strives towards economic efficiency whereas corporate interpretations and sense-making in and of changing normative environments, predispositions for acting in the first place, are not considered. This is surprising since we can think of the emergence of CSR and global governance as a long-term crisis and challenge for MNEs as they become confronted with new social expectations and normative demands. ${ }^{7}$ In fact, as will be discussed below, definitions of what it means to be a multinational enterprise are currently being renegotiated as MNEs make sense of and respond, in one way or another, to ever-louder discussions of their responsibilities and their role in larger social and political frameworks. To shed light on such processes, the article advances a single-case illustration of how Shell, in response to the crisis experienced in Nigeria during the 1990s, made sense of changing expectations and which interpretive frames and responsibilities in and of global governance the enterprise expressed thereby. ${ }^{8}$

Recognizing that MNEs are permanently engaged in sense-making because their environments are characterized by emergent meaning and ambiguity,

6 The notion of sense-making in this context is adapted from Senge (2006) and Ancona et al. (2007) and refers to the challenge that MNEs as learning organizations are constantly struggling to understand not only the business but also the social contexts they operate in.

7 See among many others Griffin and Prakash (2014); Woll (2010); Scherer et al. (2009); Wolf (2008).

8 Given that enterprises are legal entities, the organization itself obviously does not act nor engage in sense-making in any literal sense. Following Franke and Roos's (2010) argument, however, one can perceive of enterprises as 'structures of practice,' which feature individuals as corporate representatives acting on behalf of the enterprise. As such, for all intended purposes at hand, MNEs do engage in sense-making of their environment, and if this includes reflections on the corporate role vis-à-vis society and nation-states, they refer arguably to the enterprise's role and responsibilities in global governance. 
the paper proposes to conceptualize corporate agency in social and creative terms. The notion to do so has already been advanced in various disciplines including IR and International Political Economy (IPE) ${ }^{9}$, Economic Sociology ${ }^{10}$, International Business and Management Studies ${ }^{11}$, Business Ethics ${ }^{12}$, Organization Studies ${ }^{13}$, and Geography ${ }^{14}$ but has not been applied to conceptualize MNEs and their agency within global governance in particular. By conceptualizing corporate agency as social and creative based on the works of Emirbayer (1997) and Joas (1997), the article thus goes beyond the existing literature on global governance and CSR. More specifically, the article provides a framework to understand corporate agency and consider processes of sense-making as well as interpretive frames advanced by these actors. From within such a framework, both the generic notion of corporate rationality as well as ethical considerations enterprises should live up to appear to be too abstract to either serve as the bottom line for corporate decision-making or help the social scientist understand these decisions. Rather, corporate agency and consequentially corporate meanings are discussed as contingent functions of socially shared expectations and normative demands advanced towards MNEs which respond to these expectations in creative and probing ways.

As suggested in the opening quote, discussing MNEs in this fashion is intended as a means to gain "insight into their conduct [to not] lose the clew to bettering conditions." 15 Considering the creative and social nature of corporate agency hence not only presents an alternative how to study MNEs in global governance but also potentially provides new insights on how to govern them. Looking in particular at interpretive frames in a critical case is intended to qualify the conventional logic of corporate cheap talk. As will be argued below, interpretive frames are relevant and foundational for corporate action. To uncover these frames, the article is organized as follows. The first section spells out the limitations of a global governance framework on MNEs mentioned above. The second section develops a theoretical framework that considers MNEs as social and creative actors. To illustrate the framework, the third section considers interpretations and self-understandings advanced by Shell in Nigeria in response to its crisis during the 1990s. For reasons discussed below, findings from this case focused on how one enterprise in a particular crisis made sense of its social environments, framed its

9 Brown et al. (2010); Woll (2008); Amoore (2006); Levy and Prakash (2003).

10 Heidenreich (2012); Holzer (2010); Beckert (2003).

11 Geppert and Dörrenbächer (2014); Kostova et al. (2008), Geppert (2003).

12 Scherer et al. (2006); Matten and Crane (2005).

13 Soule (2012); Kristensen and Zeitlin (2005).

14 O'Neill and Graham-Gibson (1999).

15 Dewey (1922), 146. 
responsibilities in global governance, and responded to changing expectations and normative demands in creative yet socially contingent ways offer important insights for broader discussions on CSR and global governance. Based on these insights, the article concludes by outlining both the conceptual and theoretical, as well as the political and practical challenges of studying and meaningfully integrating MNEs into new modes of global governance.

\section{MNEs in global governance-the structural framework, its limitations, and attempts to go beyond}

Given its emphasis on non-state actors in world politics, global governance's rise to intellectual prominence in IR strongly affected and continues to affect the subfield's discussion on MNEs as well as gave the interdisciplinary discourse on CSR a distinct political twist. ${ }^{16}$ Within these discussions, MNEs are featured as showcase examples of how the provision of governance in a globalized world has changed and no longer only includes states. More specifically, corporate actors (have to) redefine their roles and responsibilities as they need to be responsive to both economic and social expectations. As a consequence of MNEs adopting new responsibilities and, as 'global governors,' becoming more involved in the provision of collective goods, the distinction between private and public becomes increasingly blurred. Whether through self-regulatory initiatives or in multi-stakeholder partnerships, MNEs are no longer confined to economic responsibilities but play (or at least should play) a more engaged role in and vis-à-vis society. ${ }^{17}$ Compared to states and their limited capabilities, the potential of as well as the need for MNEs to become 'global governors,' so the argument continues, lies in their unique organizational structure and the cross-border nature of their operations:

"TNCs have gone global and function in near real time, leaving behind the slower moving, state-mediated inter-national world of arm's-length economic transactions and traditional legal mechanisms, even as they depend on that world for their licenses to operate and protect their property right." 18

16 Barnett and Sikkink (2008) on global governance and Scherer et al. (2016) on political CSR.

17 For the same argument from different perspectives see Kobrin (2009); Wolf (2008); Prakash (2002). For particular normative takes on the issue see Holzer (2010) and Scherer et al. (2006).

18 Ruggie (2004), 487. 
As such, global governance and its focus on CSR not only provides a framework but also a strong and compelling rationale to engage with MNEs, both intellectually as well as in political practice. In this sense, global governance and its recent debates in IR enormously contributed to the study of MNEs by not only (re-)stating their importance for world politics but also by drawing our attention to normative issues. In many ways, this has motivated scholars to engage with business which in turn enhanced our knowledge about these actors and their role in today's world and established an intellectual field "notable for both its conceptual novelty and practical importance." ${ }^{19}$ To be more precise, because of its inherent emphasis on governance and corporate responsibilities current research focuses mostly on the design of individual arrangements enterprises engage with and on corporate compliance within instead of considering individual enterprises, their normative environments, or their interpretations thereof based on idiosyncratic corporate histories and governance cultures. ${ }^{20}$ Discussed mainly through the prism of governance and responsibilities, MNE research in fact "has been hamstrung" 21 in its overall development. In other word, there is a propensity to study MNEs only to the extent that they participate in governance arrangements, which impedes research from considering enterprises as actors in their own right. While their involvement in global governance is discussed in detail, we only have a limited understanding of what constitutes these actors and their agency in the first place and how they sustain their agency in light of changing expectations. ${ }^{22}$

Three limitations of this framework stand out in particular. ${ }^{23}$ First, global governance in general and the notion of CSR in particular are based in and argumentatively draw from a functionalist logic. This logic not only assumes that problems, which arise from corporate activities across borders, can be compartmentalized into tractable and manageable parts. It also argues that such problems can be solved most efficiently through deliberation and cooperation between different

19 Whelan (2012), 709.

20 The fact that the proliferating literature on individual initiatives such as the UN Global Compact, the Extractive Industry Transparency Initiative, the Voluntary Principles on Security and Human Rights, or the Forest Stewardship Council by far-at least in IR-surpasses the amount of case studies on particular enterprises is telling in this context.

21 Whelan (2012), 709.

22 Deitelhoff and Wolf (2010). To paraphrase Woll (2010), 138, MNEs and their interests are "used to do the explaining; they are not what needs to be explained."

23 Obviously, these limitations reflect a stylized critique of how MNEs are currently studied in IR and hence does not do justice to individual research. It is stylized in the sense that no single publication explicitly frames itself in functionalist, structural, and rational terms. Nevertheless, we find all three perpetuated and collectively reproduced one way or another. 
stakeholders. ${ }^{24}$ We find this "managerial vision of how to deal with global problems" 25 in the practitioners' discourse but we also see it in academic reflections. Integrating MNEs into governance is not only assumed to be functionally necessary. Rather, given their resources and organizational advantages, initiatives engaging MNEs are perceived to provide better governance. Hence, often presented as an unavoidable consequence of globalization, the integration of MNEs into global governance appears to be almost without alternatives, which is why the literature is equally committed to positively describing as well as normatively prescribing corporate behavior. ${ }^{26}$ Emphasizing responsibilities MNEs should meet on functionalistic grounds, however, leaves global governance and its CSR discussion normatively biased towards integrating MNEs and arguably too optimistic in its conclusions about the role of business and the potential of 'moralizing the corporation.' 27

Second, given its interest in order, structure, and public goods, global governance inevitably features a certain disregard for agency. As Weiss and Wilkinson put it, global governance is about nothing less than "how the world is governed."28 Hence, we tend to think of global governance and CSR in structural and passive rather than agential terms and hence exogenize processes which constitute MNEs in their agency. Their engagement in CSR and global governance is not only a priori stated but also presented in reactive terms as enterprises are increasingly conceptualized as elements and pieces of global governance rather than probing and active entities. ${ }^{29}$ In other words, MNEs are assumed to serve as global governors and as such provide public goods while contingent and potentially contested processes, which constitute and reproduce their agency both within the enterprise, among shareholders, and in society at large, are not considered. In fact, being predominantly viewed as 'structural force,' MNEs only recently "received attention within academic debates in international relations-at least as an actor in its own right." 30

24 Börzel and Risse (2010), 126-28.

25 Sinclair (2012), 5.

26 Whelan (2012), 711-2.

27 For two examples of such optimistic accounts in general see Holzer (2010) and Ruggie (2004).

28 Weiss and Wilkinson (2014), 25.

29 For an example of conceptualizing MNEs as elements rather than actors see Karns et al. (2015). See Avant et al. (2010) for a critique of this approach and advancing a relational alternative to discuss various actors in global governance. For a critical account of the absence of theorizing agency in global governance see Finnemore (2014).

30 Deitelhoff and Wolf (2010), 5 . This can be read as a broader critique on methodological individualism as well which cannot conceptualize the social and creative dimension of corporate agency as it reduces "the concrete, meaning-oriented activity of an agent to something that approaches stimulus-response behavior" (Goddard and Nexon (2005), 14). 
Third, and following from this structural disregard of agency, global governance in general and those accounts of CSR which argue in favor of a business case in particular are framed in an 'economic paradigm' relying on a corporate image which assume that MNEs act rationally and in a unitary fashion. ${ }^{31}$ In this vein, a very diverse and heterogeneous group is conceptually essentialized in its meanings as well as rationalized in its mode of action. Although such an actor image and its application have for a long time been criticized in various ways and disciplines, MNEs are still commonly "understood as essentially rational actors whose expansionary behavior can be explained through the profit motive." 32 This is troublesome because in retrospect, "it is always possible to reconstruct the economic rationality that firms were apparently pursuing." 33 As such, the notion of corporate rationality in conceptual terms enters MNE research in two different ways: It is a priori assumed before empirically engaging with MNEs, and then post hoc theoretically reported as a finding. This tautological use of corporate rationality does not provide an adequate foundation neither for an enterprise to purposely choose between alternatives and act in light of uncertain and indeterminate situations nor for the social scientist to explain such action. ${ }^{34}$

Against these limitations and the broader interest in governance they stem from, IR and IPE recently witnessed an explosion of literature on the subject that advanced new and more sophisticated understandings of MNEs. Recognizing changes in the interaction between states, corporate actors, and civil society, these contributions more emphatically consider MNEs in their social and political environments, both in rational and non-rational terms. ${ }^{35}$ Moreover, in interdisciplinary terms, a broad range of micro-foundational, agency-based contributions

31 Scherer et al. (2016), 8-9.

32 Amoore (2000), 184. In his introduction, Palan (2000) echoes the same concerns.

33 Woll (2008), 4. The consideration of reputation as a new variable of why MNEs join governance arrangements can be read as a post hoc explanation. Corporate rationality in this sense can be advanced to explain both more and less engagement in global governance: While Sundaram and Inkpen (2004) advance their notion of corporate rationality to make a case for a narrow definition of corporate responsibilities, Pies et al. (2009) usesh rational reasoning to argue the opposite and conclude that MNEs- “judged by the criterion of prudent self-interest" — should become broadly engaged as global governors and assume different responsibilities. The overall explanatory value of this concept, however, appears rather limited, if differing corporate actions are equally explainable using the same frame.

34 Beckert (2003), 782-83. Also see Zeitlin (2007) who critically discusses such an understanding of corporate rationality as 'hyper-rationality.'

35 Rational accounts discussing MNEs in substantial terms would include, among others, Eden and Dobson (2005); Jensen (2006); Gillies (2010); Kinderman (2012); Börzel and Thauer (2013); Griffin and Prakash (2014); and Berliner and Prakash (2015) while non-rational MNE research, either self-labelled or depicted as such, would include Cutler (2008); Woll (2008, 2010); Brown 
on MNEs connects to this research and argues in favor of conceptualizing corporate actors as social and dynamic organizations embedded in ever-changing normative environments. ${ }^{36}$ However, while recently gaining more prominence in and beyond IR and IPE and thus providing inspiration for the framework to be advanced below, research explicitly focused on the actor status and agency of MNEs still remains at the sidelines, with contributions in IR and IPE substantially discussing corporate governance contributions rather than theorizing corporate agency. While rational accounts in this vein tend to conceptualize MNE behavior in passive terms or disregard the individual enterprise in favor of macro-level FDI flows, non-rational accounts tend to substitute instrumental motivation with ethical considerations based in a logic of appropriateness. In particular, constructivist accounts seem to put too much emphasis on normative structures and hence leave little room for creativity or agency in general for that matter. ${ }^{37}$ Hence, despite discussing MNEs, their roles, and their responses to changing environments, only few contributions have explored corporate agency in global governance yet. ${ }^{38}$

This is insofar surprising as global governance and the notion of CSR raise "very basic question[s] about the social definition of a corporation." 39 Relying on non-agential frameworks either based in the economic paradigm of corporate rationality or in ethical discussions emphasizing the need to act appropriately, disregards corporate agency and does not provide a foundation to consider corporate sense-making. While recent contributions in and beyond IR and IPE seem to recognize the need to do so and point in this direction, the task to "endogeniz[e] actor creation into our understandings of global governance" by turning MNEs into "something we treat as an object of research and want to understand conceptually and theoretically" has not been completed yet. ${ }^{40}$ Understanding MNEs in this way,

et al. (2010); Flohr et al. (2010); Hofferberth et al. (2011); Dashwood (2012); Brühl and Hofferberth (2013); Farrell and Newman (2015); and Abdelal (2015).

36 This includes contributions in Economic Sociology, International Business and Management Studies, and Organization Studies drawing from March and Olsen (1989) and Powell and DiMaggio (1991). Business Ethics further contributes to this by emphasizing social responsibilities of MNEs and thereby opens a discussion on "the role that transnational corporations should play in global governance" (Scherer et al. (2006), 505, emphasis added).

37 See for example Kollman (2008); Flohr et al. (2010); and Brown et al. (2010) and their emphasis on norms. A broader critique of constructivism and structural focus expressed within has recently been developed by Finnemore (2014) and Hofferberth and Weber (2015).

38 This abridged and stylized judgment is not intended to do justice to the undeniable richness of individual contributions but rather sets the argumentative stage for the framework below.

39 Kobrin (2008), 267.

40 Finnemore (2014), 223. Cutler (2008), 195, shares this view and reminds us of the implications of the "ontology and conceptualization of corporate form" we advance in our research. 
however, is important since MNEs indeed engage more actively in governance than before. However, such engagements alone do not turn MNEs into global governors. In other words, the empirical observation that MNEs more actively contribute to global governance and thus respond to broader social expectations alone tell us very little about why they do so and which responsibilities they ultimately accept within this context. In order to provide a more detailed account, processes of corporate sense-making and interpretation that precede governance engagements need to be considered. These processes can best be reconstructed if one considers corporate agency in social and creative terms.

\section{Social meanings and creative agency-the agential framework}

In order to consider how MNEs make sense of their normative environments and which corporate responsibilities and broader understandings they express thereby, the article argues that their agency cannot be conceptualized in fixed terms from within a static ontology assuming a 'corporate essence.' The notions of corporate rationality and strategic profit maximization are prime examples for such ontological fixations. As 'conceptual shortcuts' based on theoretical a priori assumptions, both affect MNEs but are not sufficient to explain corporate action in its entire complexity, contingency, and diversity. In other words, simply being a multinational enterprise does not determine a particular course of action. For one, the notion of profit is not defined in specific enough terms but has to be filled with meaning in particular situations as the corporate objective of seeking profit does not imply clear enough definitions how to succeed in maximizing it. ${ }^{41}$ For another, corporate decisions in order to realize situationally specified objectives are no more rational than the situational pursuit of what is perceived as the 'best alternative.' ${ }^{42}$ Consequentially, if corporate agency is no longer perceived as "simply making a different selection from a reservoir of situation components that are either already defined or have no need of definition" but rather reflects attempts of "defining that which is as yet undefined," 43 the very basics of what it means to be a multinational enterprise and which corporate responsibilities follow from this become subject to debate. Hence, corporate agency and

41 Fontrodona and Sison (2006), 37-8. I would like to thank one of the reviewers for pushing me into the direction of distinguishing between profit seeking and profit maximizing.

42 Sabel and Zeitlin (1997), 6-7.

43 Joas (1997), 133. 
meanings can both be thought of as dynamic outcomes of socially contested, openended processes of sense-making involving MNEs and relevant others.

To further conceptualize corporate agency and meaning, it is instructive to consider in particular their social and creative dimensions. Given the complex social relationships MNEs find themselves in, as well as diverse normative expectations originating from cross-border activities in different social and cultural contexts, consequences of their actions are never clear and hence can only guide corporate decision-making to a certain extent. Above and beyond, MNEs have to interpret and connect to social expectations and shared understandings to maintain their agency. More explicitly, corporate agency resides in "the interpretive processes whereby choices are imagined, evaluated, and contingently reconstructed [...] in ongoing dialogue with unfolding situations." 44 As such, social contexts are constitutive for corporate agency since MNEs "must engage in a process of creating some level of a shared understanding of what constitutes the rule system." 45 Because of their cross-border operations, MNEs must reconcile expectations from different stakeholders situated in different, potentially contradicting social contexts. Facing these pressures, MNEs relate to their social contexts by integrating particular expectations into their actions while disregarding others. As such, MNEs are situated in social relations without being determined by them:

"Actors do not behave or decide as atoms outside a social context, nor do they adhere slavishly to a script written for them by the particular intersection of social categories that they happen to occupy. Their attempts at purposive action are instead embedded in concrete, ongoing systems of social relations." 46

The implication of this proposition is the comprehensive qualification of corporate action based on rational calculations and fixed notions of profit. Such calculations as well as the fixation of objectives logically depend on the assumption of individualized and pre-constituted actors independent from social interaction whose actions are conceptually considered as being 'caused' by anticipated consequences. ${ }^{47}$

44 Emirbayer and Mische (1998), 966. Note that this argument qualifies the 'cheap talk' notion often held against corporate rhetoric: While clearly instrumental in their CSR communication, the conscious creation and dissemination of interpretive frames entails certain basic assumptions and understandings held by MNEs which can be considered as foundational for the actions and decisions they pursue (Wickert et al. (2016)).

45 Kostova et al. (2008), 1002.

46 Granovetter (1985), 487.

47 Coleman (1986) provides a sophisticated theory of action situated in such an individualistic and rational framework, which is often applied to MNEs. See for example Börzel et al. (2013) who distinguish MNEs from other actors by fixating their interests: "Unlike states and civil society actors, firms are not committed to the public good but the pursuit of private interests. Their business is to maximize profits, not social welfare." 
Contrary to such an atomistic perspective on agency which considers MNEs to be informed by instrumental reasoning and not engaged in processes of sensemaking, we can imagine MNEs to conceive themselves and their actions only in relation to and in interaction with others. ${ }^{48}$ Corporate preferences, obviously necessary preconditions to act, resonate with and in fact must reconcile social meanings of what constitutes MNEs as MNEs. These broader meanings have to be actualized in specific situations. For example, notions of corporate responsibility and profit-maximization are important points of reference and orientation for MNEs yet they are specified situationally in response to "contexts that are themselves ever changing and thus always subject to reevaluation and reconstruction of the part of the reflective intelligence." ${ }^{49}$ Ultimately, it is their sociality that allows MNEs to access intersubjective meanings to assess and make sense of a situation at hand and thereby sustain agency by constantly translating general notions and ideas of what it means to be a multinational enterprise into specific action. ${ }^{50}$

Given the indeterminate nature of meanings and social contexts in which they emerge, sustaining agency also depends on the actor's creativity and inventiveness to relate to, make sense of, and ultimately choose between different meanings available in any given situation. The notion of creativity in this context should not be confused with extraordinary artistic or interpretive skills. Rather, just like sociality, creativity is indispensable in order to maintain agency. Just as any organization, MNEs "carry out practices that are simultaneously constrained (in some direction) and empowered (in others) by the existing social structure." 51 However, while situations are to some extent socially structured and the horizon of actions available to MNEs is socially derived, there is always a range of different readings

48 Whelan (2012), 710.

49 Emirbayer and Mische (1997), 967-68. To be sure, against this background of constant flux, actors develop routines to ease their processes of ongoing reflection and reevaluation. Specifically MNEs "engage in simplification processes using cognitive tools such as scripts, schemas, and typifications so as to bring some order to their understanding" (Kostova et al. (2008), 1002). The notion of profit maximization is illustrative in this context as it clearly reflects a sedimented and hence stable social routine. As such, it influences MNEs and can almost be considered as a defining characteristic. However, even established routines are of limited value when encountering novel situations and experiencing crises. In such situations, profit-maximization only marks a viable yet abstract and therefore ultimately unassertive aspect of what it means to be an enterprise and how to act as such. In the end, the notion of profit remains "only loosely defined at any given moment and is constantly being redefined" (Sabel and Zeitlin (1997), 15). In other words, while it may mark the 'default option' for corporate decisions, profit maximization does not easily translate into specific action and must be actualized and given meaning in any particular situation.

50 Beckert (2003), 775-79.

51 Scott (2008), 77. 
and interpretations available for any given situation. Choosing between those depends on how MNEs creatively relate to certain and dismiss other meanings, which will then translate into a specific course of action. ${ }^{52}$ Put differently, the open and indeterminate nature of social situations mandates that actors continuously relate to existing meanings while they at the same time create novel meaning. Which particular interpretations a MNE advances to make sense of a specific situation, which existing meanings and social expectations it connects to and which it disregards, and which course of action it ultimately sets itself on, all reflect choices that have to be realized and, taken together, constitute a creative process of sensemaking which sustains agency. ${ }^{53}$

With both spelled out in some detail, it is important to emphasize that neither sociality nor creativity automatically implies 'successful' action. Rather, they only constitute and sustain agency. Since corporate action plays out against indeterminate social situations, MNEs depend on "interpretative acts by which [they] construct perceptions of rationality intersubjectively in the action process itself." 54 Put differently, MNEs make sense of a situation at hand and discover their interests and opportunities as action proceeds. As such, creative agency and socially shared meanings can be thought of in a mutually constitutive and sequentially evolving relationship: MNEs depend on and have to interpret expectations and intersubjective notions of what it means to be an enterprise. At the same time, these meanings are constantly changing. Hence, in any given situation, corporate actors draw on and actualize certain meanings and this selection influences the reservoir of meanings available in future situations. As such, how MNEs act is informed by and at the same time constitutes what MNEs are. While never fully matching each other, corporate actions and notions of what constitutes an MNE "compensate for one another." 55 Corporate agency thus reflects and reproduces the boundaries of what it means to be a multinational enterprise. Consequentially, avoiding any instrumental or ethical $a$ priori assumptions, we need to consider MNEs in an open-ended fashion. How they ascribe meaning to a situation, construct their own rationalities, and translate them into action has to be reconstructed:

\footnotetext{
“[M]ultinational enterprises are viewed no longer simply as instrumentalist advantage-maximizing institutions, but as complex organizations which exceed their goals and functions, but in non-utilitarian ways. Their language, their scripts, their histories, their techno-structures

52 This notion of agency and its conceptualizations of social structures and situational creativity is grounded in American Pragmatism and discussed in detail by Hellmann (2009).

53 For a full elaboration of the notion of creative action, see Joas (1997), 145-95.

54 Beckert (2003), 770.

55 Brunsson (1989), 168.
} 
and artefacts matter; analysis of which reveals them to be trapped in their own evolutionary logic but also constantly at work to renew themselves." 56

As argued in the previous section, global governance, a renewed debate on corporate responsibilities, and the changes in the normative environment for business both entail can be thought of as a long-term crisis for corporate actors since it challenges their "deeply ingrained habits and procedures based on unarticulated knowledge and beliefs." ${ }^{57}$ Because of increased integration into governance arrangements, MNEs find themselves exposed to new expectations and in situations in which routinized and patterned courses of action no longer work. In other words, global governance initiated a debate on corporate responsibilities and in this sense reflects a "fragmented, ill-defined, and constantly evolving" normative frame for MNEs in which corporate agency has to be "reflected not only in their varying degree of compliance to institutional pressure [...] but also in that they must make sense of, manipulate, negotiate, and partially construct their institutional environments." ${ }^{58}$ This long-term crisis manifests itself in concrete situations in which MNEs face social pressure and have to construct, justify, accept, and deny responsibilities. Through these processes of sense-making, MNEs constitute new meanings. By considering Shell in crisis and by reconstructing its self-descriptions offered in response to it, the following section provides an illustration for the framework introduced.

\section{Corporate agency and meanings in crisis: Shell in Nigeria}

The article advances a single case study from the extractive industry sector to illustrate the framework introduced above. Given that the framework represents what Jackson and Nexon have called a 'scientific ontology, 59 the illustration should not be read as test for the framework proposed nor does it aim at a set of generalizable assumptions for enterprises in crisis. Rather, the single, in-depth illustration is advanced to indicate the indeterminate nature of corporate agency and meanings in a particular crisis and to reveal the interpretive frames and corporate self-understanding advanced by a particular enterprise in response. ${ }^{60}$ Representing one of the largest extractive MNEs globally and arguably the most existential crisis the enterprise has been involved in recently, the article focuses

56 Palan (2000), 15.

57 Scott (2008), 82.

58 Kostova et al. (2008), 1001.

59 Jackson and Nexon (2013), 550-52.

60 See Yin (2013) on the value of single case studies. 
on Shell and its experience in Nigeria during the 1990s. ${ }^{61}$ With its investments and operations based on geological imperatives and its long history of internationalization and cross-border activities, Shell epitomizes the ambiguities and challenges global governance and a renewed discussion on CSR entails for MNEs for three reasons. First, the high asset specificity of its investments made it very costly if not impossible for the enterprise to divest and leave. ${ }^{62}$ Second, since relying on host governments to grant rights and licenses for exploration and drilling, Shell in general and in particular in Nigeria has a history of cooperating with 'rentier states' despite the fact that such states feature limited respect for human rights and are characterized by social tensions or, in some cases, even widespread violence. ${ }^{63}$ Third and finally, as a large and globalized enterprise, Shell is vertically integrated and includes the full value chain from exploration to processing to distribution to resale within its corporate entities and subsidiaries which make the enterprise not only visible in everyday consumer experiences but also an obvious target for consumer boycotts. ${ }^{64}$

In addition to these general remarks applicable to all extractive enterprises in global governance, the case of Shell in Nigeria is specifically relevant since it represents one of the first instances where activists and policy-makers challenged an enterprise in its role and called for a more active commitment to conflict-prevention efforts as traditional, state-dominated mechanisms to solve the crisis and deescalate the conflict failed. As will be shown below, Shell's corporate responsibilities in this context became subject to debate and the enterprise had to respond in one way or another. In this sense, the crisis-following the debate on Apartheid, divestment in South Africa, and the emerging Sullivan Principles-gave further momentum to the notion of CSR and opened the stage for a more foundational reconsideration of the role of MNEs vis-à-vis society and states. The Nigerian experience did so in particular because the case highlighted the delicate role enterprises play in zones of conflict characterized by violence and wide spread violations of human rights. ${ }^{65}$ Hence, while featuring idiosyncratic dynamics, this case is of crucial importance to understand the overall development of CSR and

61 I use the term "Shell" to refer to the entire Royal Dutch/Shell group of enterprises and subsidiaries. References to specific subsidiaries include their location (e.g. Shell Nigeria).

62 Soares de Oliveira (2007), 211-15.

63 Kaldor (2007).

64 Gillies (2010), 104-6.

65 Haufler (2010), 117-27. We can explain the later introduction of the already mentioned Voluntary Principles on Security and Human Rights as a direct response to the development in Nigeria and thus further highlighting the relevance of the case (Hofferberth (2011)). 
global governance during the 1990s, which ultimately led to the UN Global Compact and the normative discussions we are engaged in today. ${ }^{66}$

With initial explorations first licensed in the 1930s and the Shell Petroleum Development Company (SPDC) founded as the Nigerian subsidiary in the 1950s, Shell has been active in Nigeria for a long time and continues to be despite a military regime assuming power in 1983. Until today, Nigeria's economy heavily depends on the petroleum and gas sector, and Shell remains the largest extractive enterprise active in the country. Consequentially, no other enterprise is as present in every-day life, and, vice versa, no other country is of equal economic importance for the enterprise. Production is organized in joint ventures under a Joint Operating Agreement between SPDC and the Nigerian National Petroleum Corporation. A Memorandum of Understanding between Shell and the federal government states that day-to-day responsibilities for operating the approximately 190 oil fields in the Niger Delta lie with SPDC. Overall, SPDC accounts for more than 40 percent of the total oil production in Nigeria and the majority of its facilities can be found onshore in ecologically sensitive yet densely populated communities. ${ }^{67}$

Against this background, political and social conflicts in the early 1990s escalated and tensions rose. Particularly the issues of regional autonomy as well as how to distribute oil revenues between different ethnic groups, of which the Ogoni constitute the largest, remained contested and caused political disagreement as well as interethnic strife for control over land containing oil wells. Beyond political issues and ethnic struggles, environmental degradation as well as failure to improve living standards despite increased oil production added to the overall volatile situation, which in late 1992 erupted into open conflict. At this time, Shell and its facilities became the target of both peaceful protest and violent actions and the enterprise had to suspend its operations in the Niger Delta. ${ }^{68}$ The crisis soon received global attention and Shell's reaction to the protests in particular sparked further criticism from Western civil society as well as further violence and anti-oil activism locally. As will be shown in the documents below, Shell initially did not condemn measures taken by the Nigerian government against the protestors nor engaged in dialogue and consolidation with local community

66 See Haufler (2001), 15-20, for a general overview of the integration of MNEs into global governance. Note that the report of the UN Commission on Global Governance and the notion to integrate MNEs occurred at around the same time (Sagafi-nejad (2008), 195-98).

67 Lambooy and Rancourt (2008), 233-34.

68 Zimmer (2010), 61-62 and 75-76. While SPDC has become active again in other regions in Nigeria, it has "produced no oil or gas in Ogoniland since then and access to the area has been limited," http://www.shell.com.ng/environment-society/our-response/unep-faq.html, accessed April 2016. 
groups. Instead, the enterprise relied on state security forces to protect its facilities and the Nigerian government quickly responded by sending military forces which led to "repression, torture, looting, rape and extra-judicial killings"69 against those who already felt mistreated. The ensuing militarization of the Niger Delta climaxed in the arrest and death sentence of Ken Saro-Wiwa and eight other Ogoni activists in May 1994 in what seemed to many a show trial. Their executions in November 1995 led to further outcries and allegations of complicity as Shell was accused of cooperating with the military junta and called upon to divest from Nigeria. ${ }^{70}$

The boycotts and scandals following the company's decision to stay in South Africa's apartheid regime during the 1980s and the proposed sinking of the Brent Spar oil storage buoy in 1995 aside, the developments in Nigeria clearly stand out as the largest crisis in Shell's recent corporate history. ${ }^{71}$ Activists, both local and global, challenged the legitimacy of Shell as a socially responsible enterprise and called for boycotts. Not being able to continue operations in certain regions in Nigeria, the reputational losses also directly translated into financial losses. Hence, more than ever, the enterprise depended on creatively maintaining agency as established routines no longer worked and no obvious responses or predefined courses of corporate action were readily available. ${ }^{72}$ For the purpose at hand-illustrating that corporate agency matters and that it depends on creativity and sociality - the case of Shell in Nigeria thus offers a highly salient case of corporate exposure as the enterprise had to deal with a complex and novel situation in which prior corporate meanings no longer sufficed to sustain agency. In this crisis, new social expectations emerged, prior interpretations became obsolete, and Shell was challenged to reconsider its role and responsibilities. In other words, "the rules and norms of socially acceptable decision making - the institutionalized environments of the corporation-[were] in flux"73 and Shell had to respond to these developments.

In order to reconstruct how Shell interpreted the crisis, corporate documents were analyzed since these constitute the link between corporate interpretations (connecting to social meanings) and corporate actions (based on creative agency). While not necessarily corresponding one-to-one with corporate action, the interpretive frames advanced within these documents reflect attempts to

69 Omeje (2006), 142.

70 Zimmer (2010), 75-76.

71 Lawrence (2002). For a general account of the enterprise's history during these years with a particular focus on South Africa, Brent Spar, and Nigeria, see Sluyterman (2007), 301-65.

72 Soule (2012), 1716-7.

73 Holzer (2010), 121. Obviously, the focus on crisis biases the findings but at the same time reveals corporate agency most clearly. For studies on corporate sense-making under more routinized conditions, see Geppert (2003) and Kristensen and Zeitlin (2005). 
define the issue and the appropriate responsibilities which follow from it. ${ }^{74}$ To the extent that they reflect attempts to make sense of the crisis and establish and justify new corporate meanings, the documents represent the foundation on which actions were taken and hence can be considered as an indispensable [...] source of information about the range and robustness of the constraints [MNEs] faced." 75 In other words, based on the theoretical framework outlined above, these documents were not considered as corporate 'cheap talk' or 'public relation ploy.' Rather, while rhetorical in nature and published with the intent to present the enterprise in a positive light, these documents and the interpretive frames advanced within reflect corporate agency as much as action does and express particular meanings and self-understandings. More specifically, they reflect how Shell perceived and interpreted the crisis, which expectations the enterprise considered as relevant and appropriate, and which corporate responsibilities it accepted in response. All in all, despite commercial imperatives and issues of liability, the documents reflect the processes of sense-making that Shell had to engage in to deal with a crisis and the novel social expectations it entailed. ${ }^{76}$

These interpretive processes were reconstructed by considering the four major documents published by Shell in response and in hindsight to the crisis. Targeted at a broader audience and made publicly available, these documents reflect the enterprise's general understandings of the crisis. Focused on the general corporate role remote from day-to-day experiences or corporate activities on the ground, these documents express foundational corporate self-understandings and responsibilities accepted on behalf and in the name of the enterprise.$^{77}$ Reflecting Shell's immediate response to the Ogoni executions, a newspaper ad published in November 1995 was considered first. Shell's first sustainability report published in 1998 was analyzed as the second document. Third, the corporate statement published in response to the out-of-court settlement of the Saro-Wiwa case in June

74 Brunsson (1989), 168-73, for the general argument and Haufler (2010), 109-10, for a discussion of extractive enterprises and their interpretive frames in particular.

75 Sabel and Zeitlin (1997), 15.

76 As will be shown below, the strongest argument against disregarding corporate documents as cheap talk is empirical in nature. For one, the documents considered were surprisingly open and discussed the crisis in great detail. For another, we can trace changes in the interpretive frames advanced over time, meaning that corporate documents do not always convey the same story. Given the immediateness of the crisis and the authenticity of corporate documents available, the article refrains from using secondary data, such as interviews or NGO reports. This decision to limit the material to corporate self-descriptions should be considered as a methodologically statement to more willingly engage with such documents. If read critically, research can go beyond rhetorical narratives of corporate performance and reconstruct divergent and conflictual frames, meanings, justifications, and role-definitions expressed within.

77 Scott (2008), 85-91. 
Table 1: Corporate documents analyzed.

\begin{tabular}{|c|c|c|}
\hline Title of document & Date of publication & Document characteristics \\
\hline $\begin{array}{l}\text { Clear Thinking in } \\
\text { Troubled Times }\end{array}$ & November 21, 1995 & $\begin{array}{l}\text { International newspaper ad published in } \\
\text { response to Ken Saro-Wiwa's execution. }\end{array}$ \\
\hline $\begin{array}{l}\text { Shell Sustainability } \\
\quad \text { Report } 1998\end{array}$ & 1998 & $\begin{array}{l}\text { First official sustainability report, directly } \\
\text { related to the crisis in Nigeria. }\end{array}$ \\
\hline It is time to move on & June 12, 2009 & $\begin{array}{l}\text { Statement following the out-of-court } \\
\text { settlement of the Saro-Wiwa case. }\end{array}$ \\
\hline The Ogoni Issue & After 2009 & $\begin{array}{l}\text { General and most recent statement, not in } \\
\text { immediate response to the crisis. }\end{array}$ \\
\hline
\end{tabular}

2009 was interpreted. Finally, the most recent statement on the Ogoni Issue published online through Shell's webpage was considered. Table 1 summarizes the documents and their characteristics. This selection features the most visible and hence important corporate documents published by Shell. ${ }^{78}$

Across these four documents, there is no clear message that Shell conveys in response to the crisis and its role and responsibilities in Nigeria. Overall, the documents do not show a consistent interpretive framework advanced to make sense of the crisis nor do they feature a clear, discernible strategy on how to deal with it. Whereas the first document aggressively dismisses any criticism and can be read as a self-righteous attempt to blame others for what happened in Nigeria, the latter documents are much more cautious and considerate in their accounts of what has happened and how to respond to it. In addition to differences as to how Shell frames the crisis and its relation to other actors, the documents clearly differ in terms of how openly the enterprise discusses the crisis in the first place. Beyond these differences in style and tone, however, Shell overall is clearly committed

78 With the exception of the first, all documents were still publicly available at the time of research. For obvious reasons, obtaining corporate documents can be challenging. Other than for parliamentary statements or official state documents, there are no archives. A comprehensive scanning of all corporate documents revealed that Shell only published this handful of documents that directly, and in a substantial way, discussed the crisis in Nigeria. While 'secondary' communication through business associations, other governance arrangements, and multi-stakeholder initiatives was considered in initial research, it was not included in this study because Shell really only began to engage in those after the crisis and there was very little to be found on this aggregated level that explicitly dealt with Nigeria. More importantly, it was impossible to discern whether a particular statement was made in the name of Shell or issued on behalf of the initiative such as the Voluntary Principles on Security and Human Rights which Shell joined later (Hofferberth (2011)). 
Table 2: Crisis sense-making and corporate self-understandings expressed by Shell in Nigeria, 1995-2009.

\begin{tabular}{|c|c|c|c|c|}
\hline & $\begin{array}{l}\text { Document } 1 \text { (1995) } \\
\text { Clear Thinking in Troubled Times }\end{array}$ & $\begin{array}{l}\text { Document } 2 \text { (1998) } \\
\text { Shell Sustainability } \\
\text { Report } 1998\end{array}$ & $\begin{array}{l}\text { Document } 3 \text { (2009) } \\
\text { It is time to move on }\end{array}$ & $\begin{array}{l}\text { Document } 4 \\
\text { (after 2009) The Ogoni } \\
\text { Issue }\end{array}$ \\
\hline $\begin{array}{r}\text { Character of } \\
\text { document }\end{array}$ & $\begin{array}{l}\text { Self-righteous and aggressive } \\
\text { response to criticism }\end{array}$ & $\begin{array}{l}\text { Open, explicit, and rather } \\
\text { detailed }\end{array}$ & $\begin{array}{l}\text { Personal and emotional } \\
\text { without engaging } \\
\text { criticism }\end{array}$ & $\begin{array}{l}\text { Evasive and carefully } \\
\text { measured, } \\
\text { contextualizing the crisis }\end{array}$ \\
\hline $\begin{array}{l}\text { Expressed self- } \\
\text { understanding }\end{array}$ & $\begin{array}{l}\text { Exclusively as an economic actor } \\
\text { and as such morally superior }\end{array}$ & $\begin{array}{l}\text { Acting both economically } \\
\text { and socially } \\
\text { responsible }\end{array}$ & $\begin{array}{l}\text { Prudent economic actor } \\
\text { and important for } \\
\text { development }\end{array}$ & $\begin{array}{l}\text { As an economic actor which } \\
\text { may provide other } \\
\text { functions, too }\end{array}$ \\
\hline $\begin{array}{l}\text { Definition of } \\
\text { responsibilities }\end{array}$ & $\begin{array}{l}\text { Minimal responsibility, limited to } \\
\text { economic activity }\end{array}$ & $\begin{array}{l}\text { Imprecisely defined and } \\
\text { full of contradictions }\end{array}$ & $\begin{array}{l}\text { Mostly economic, but also } \\
\text { references to other } \\
\text { responsibilities }\end{array}$ & $\begin{array}{l}\text { Primary economic } \\
\text { responsibility, limited } \\
\text { engagement beyond that }\end{array}$ \\
\hline $\begin{array}{l}\text { Definition of scope } \\
\text { of corporate action }\end{array}$ & $\begin{array}{l}\text { Incapable of solving conflict, } \\
\text { dependent on government }\end{array}$ & $\begin{array}{l}\text { Capable but somehow } \\
\text { unwilling to act or } \\
\text { intervene }\end{array}$ & $\begin{array}{l}\text { Capable of acting and } \\
\text { decision-making }\end{array}$ & $\begin{array}{l}\text { Rather limited, at best only } \\
\text { supporting other actors }\end{array}$ \\
\hline Definition of crisis & $\begin{array}{l}\text { Tragedy caused by careless } \\
\text { protester and corporate critics }\end{array}$ & $\begin{array}{l}\text { Governance crisis caused } \\
\text { by Nigerian } \\
\text { government }\end{array}$ & $\begin{array}{l}\text { Downplaying conflict, } \\
\text { evading rather than } \\
\text { defining crisis }\end{array}$ & $\begin{array}{l}\text { Complex, featuring } \\
\text { political, economic, and } \\
\text { ecological dimensions }\end{array}$ \\
\hline $\begin{array}{l}\text { Relation to other } \\
\text { actors }\end{array}$ & $\begin{array}{l}\text { Very cautious towards Nigerian } \\
\text { government, very aggressive } \\
\text { towards critics and protester }\end{array}$ & $\begin{array}{l}\text { Discontent with host } \\
\text { government, other } \\
\text { actors not mentioned }\end{array}$ & $\begin{array}{l}\text { Relation to other actors } \\
\text { not explicitly } \\
\text { elaborated }\end{array}$ & $\begin{array}{l}\text { Careful articulation of } \\
\text { discontent with Nigerian } \\
\text { government }\end{array}$ \\
\hline $\begin{array}{l}\text { Response to } \\
\text { expectations }\end{array}$ & Explicit rejection & $\begin{array}{l}\text { Expectations not } \\
\text { explicitly yet implicitly } \\
\text { incorporated }\end{array}$ & $\begin{array}{l}\text { References to } \\
\text { expectations without } \\
\text { engaging them }\end{array}$ & $\begin{array}{l}\text { Diluting expectations by } \\
\text { adding additional 'facts' }\end{array}$ \\
\hline
\end{tabular}


to defining its responsibilities in economic terms. In the first document, for example, the enterprise argues in all explicitness that "[p]olitics is the business of governments and politicians" and that a "world where companies use their economic influence to prop up or bring down governments would be a frightening and bleak one indeed." This general sentiment of limited responsibilities and the attempt to separate the political from an economic realm is restated throughout all documents. Interestingly though, the second and fourth document in this context also introduces "humanitarian values" that Shell represents and defines its major contribution as "running a decent business." Thereby, while overall still maintaining a distinctively limited understanding of its own role, the enterprise at least indicates broader responsibilities and social expectations, which began to emerge during the unfolding of the crisis. While Shell does not understand these to be constitutive for an enterprise, they are still included and thus reveal a certain uncertainty about the appropriate course of action and its own role as an actor within global governance.

This paradoxical interplay between moments of stating broader responsibilities and thereby assuming agency in the crisis followed by immediate attempts to reconfirm its limited economic role becomes most visible in the 1998 Sustainability Report. Compared to the other documents, this report most clearly reflects the challenges and contradictions Shell experienced in Nigeria as well as the uncertainty how to deal with them. In this document, the crisis is described in full detail and the enterprise expresses discontent with how the Nigerian government responded to it. In addition, Shell assumes broader responsibilities by stating that "[w] will continue to promote humanitarian values in Nigeria." As the enterprise discusses the overall problematic human rights situation in Nigeria and advances ideas that are clearly above and beyond a narrow understanding of being an economic actor, neither the aggressiveness of the first nor the evasive character of the latter documents cover the cracks the crisis in Nigeria and the executions of Ken Saro-Wiva and his fellow activists have left in Shell's self-definition as a multinational enterprise. Despite these cracks, however, even in this document Shell falls back to its default position as an economic actor as the enterprise overall remains reluctant to proactively define and fully embrace broader responsibilities. Alternatives such as a more critical stance towards the Nigerian government, potential divestment, or dialogue with local communities are indicated throughout the report but ultimately not realized.

Relating this document to the others, it can be concluded that the enterprise only hesitantly and selectively responded to the crisis, overall remained indecisive, and hence, in the end, presents itself in rather contradicting ways. In other words, Shell failed to make sense of the crisis and its own role as the documents remain full of contradictions. For the most part, Shell connects to criticism and thereby 
recognizes the changing nature of social expectations yet at the same time denies their legitimacy and hence does not integrate them into its own sense-making of the crisis nor into its own behavior. Describing the conflict as a "bitter legacy, potentially undermining any reconciliation initiative, even among the Ogoni people themselves," the enterprise rather attempts to generate itself as a champion of the Ogoni cause and claims that it is engaged in and committed to "advance[ing] the process of reconciliation and support[ing] a better future for Ogonis." By doing so, it frames its own actions as humanitarian but immediately limits them to the extent that its main task is to pursue economic operations. Once these have been reestablished, no further ethical obligations for Shell can be derived despite the fact that root causes of the initial crisis have not been solved.

In summary, even though all documents have been devised and authored by public relations departments, they fail to hide the fact that Shell remains deeply uncertain about its own role and fails to make sense of the crisis and the implications which follow from it. The documents overall oscillated between claiming moral superiority vis-à-vis the critics on the one hand and granting them recognition on the other. Put differently, there is no consistent pattern to the meanings expressed by Shell as the enterprise continues to operate in a complex, normative environment facing novel expectations and demands. These contradictions within Shell's rhetoric reveal a deeper failure to make sense of the crisis and to respond to it in a meaningful way. As the enterprise engaged with the crisis, it relied on different interpretive frames and rhetorical strategies and overall "struggled to understand and respond to society's changing expectations."79 On the one hand, Shell constantly refers to the crisis in its self-descriptions and, in light of local and global protest, acquiesces that the enterprise cannot remain silent about it. On the other hand, the enterprise fails to develop clear responses or workable solutions. The overall picture shows an enterprise that is overwhelmed by the criticism and persistence of civil society, shifting from one awkward statement to the next. Put simply, not expecting activists discredited in the first document to be as influential as they turned out to be, Shell had to learn the crisis lesson the hard way.

In terms of the framework introduced above, social expectations expressed by others obviously matter for Shell. At the same time, though, the enterprise responds to them only in a limited way without fully appreciating their appropriateness. Although still struggling in the end, it is this response that reveals Shell as a social and creative actor. In this vein, the framework introduced above helps to explain "Shell's sluggish response to the unfolding debate" 80 as the enterprise failed to provide an interpretive framework on how to deal with the crisis.

79 Lawrence (2002), 76.

80 Holzer (2010), 49. 
Rather than advancing clear beliefs and expressing confidence, Shell's rhetoric appears to be a function of a 'trial-and-error' approach as the enterprise holds onto the notion of being primarily an economic actor, while at the time indicating broader responsibilities that go beyond this narrow role. As such, the documents are full of 'rhetorical stumbling' and mark poor attempts of 'damage control' of an enterprise in distress. Only in hindsight and after the immediate crisis did Shell "distance itself from the state's militaristic responses-an evidently counter-productive measure-and [since then] has been striving to develop less acrimonious relationships with host communities." ${ }^{81}$ However, given the uncertainty and indecisiveness reconstructed throughout the documents, even these recent commitments should not be misinterpreted as expressions of a fundamentally changed corporate role or a successful integration of Shell into global governance. Rather, considering the interpretive frames advanced, such engagement and consolidation through local community building cannot cover up a hesitant enterprise caught in the paradoxical attempt to somehow respond to expectations yet at the same time evade responsibility. As the enterprise states itself in 2009, its "major contribution remains to run a decent business." What precisely the idea of 'decent business' in the context of conflict, human rights violations, socio-economic tensions, and environmental degradation entails for Shell, however, remains undefined and it is these uncertainties that can be revealed when conceptualizing corporate agency as social and creative instead of framing it as rational, ethical, or otherwise pre-determined.

\section{Conclusion}

As argued throughout the article, IR's intellectual engagement with MNEs has found a new home within the narratives of global governance and CSR. This development made the subfield consider corporate actors more intensively but also brought with it certain conceptual limitations. Drawing on interdisciplinary research on MNEs as dynamic, non-rational actors as well as on social theory, the article proposed an alternative framework to consider corporate agency and meanings in their social and creative dimensions. By incorporating these two into the framework, both the social embeddedness of MNEs as well as their capacity to interpret and act creatively were considered and sequentially related: While social meanings and expectations independent of economic reasoning-Prakash and others refer to this as the nonmarket environment of $\mathrm{MNEs}^{82}$-pre-structure

81 Omeje (2006), 97.

82 Prakash (2002). 
any particular situation in which an enterprise acts, which of these meanings and expectations the enterprise connects to and how they are interpreted remains subject to situational agency. Taken together, the notion of sociality and creativity helps to conceptualize MNEs without relying on absolute, context-independent notions of corporate rationality, profit-maximization, or ethical considerations. Rather, it stresses the importance of corporate interpretations and focusses on such processes of corporate sense-making. By doing so, the framework goes beyond discussing corporate contributions within governance arrangements and hence add to our understanding of CSR and corporate agency in global governance.

While the framework can be applied to different contexts, it appears to be most useful when enterprises find themselves in crisis and new expectations towards MNEs emerge. Under such conditions, corporate interpretive processes are more foundational and hence more accessible. Independent of a crisis or not, though, engaging with interpretive frames advanced by MNEs instead of disregarding them as cheap talk appears to be promising since it puts corporate action and measures taken under the CSR frame into perspective. In this sense, rhetoric and action are two sides of the same engagement of an enterprise and hence reinforce and complement each other. ${ }^{83}$ Assuming such a link between the two, the empirical observation that enterprises engage in governance activities beyond narrow economic responsibilities, such as self-regulation or community stakeholder development alone, does not reveal under which conditions and based on which cognitive frameworks and normative beliefs they act. Arguably, these engagements only matter if they resonate with deeper changes in corporate beliefs and are based on conviction rather than only representing strategic or even opportunistic adjustments to new expectations without committing to them.

For the illustration advanced in this contribution, corporate documents published by Shell in response to the developments in Nigeria during the 1990s were perceived as manifestations of how the enterprise made sense of changing normative expectations and thereby expressed and constituted corporate responsibilities in and of global governance. Against the narrative of MNEs becoming global governors, the findings for Shell suggest a gap between academic research on the one hand and corporate self-understandings on the other hand. Contrary to more optimistic accounts concerned with what Shell did, ${ }^{84}$ considering what Shell expressed as corporate beliefs revealed an enterprise reluctant to leave its comfort zone of economic responsibilities. At the very least, we can confirm for Shell, that "when

83 Brunsson (1989), 168-73. Wickert et al (2016) frame this as CSR talk and CSR walk which together constitute the overall CSR engagement of a particular enterprise.

84 Lambooy and Rancourt (2008); Lawrence (2002). 
faced with new stakes, firms are initially confused and need to learn about their nature and functioning." 85 Throughout all documents, the enterprise held onto the notion that the private and the public should remain separated and defined itself as an economic actor with limited responsibilities for the crisis and beyond. Despite engaging in a reconciliation process after 2005, funding community projects, and initial commitment to clean-up oil spills, Shell rhetorically did not express a broader range of social responsibilities, and the documents overall appear as defensive measures taken by an enterprise uncertain about its own role. While Shell concluded that business has to be conducted decently, the enterprise failed to specify what this notion entails and entangled itself in contradictions. Consequentially, for those instances were Shell provided compensation and governance, it can be assumed that these did not reflect deeper normative changes but rather marked strategic or opportunistic adjustments.

If corporate engagement in global governance remains limited to the latter, much of the optimism on MNEs becoming global governors and the paradigm shift from adversarial to more cooperative approaches towards business appears to be unwarranted. Integrating hesitant and uncertain enterprises, such as Shell, meaningfully into robust structures of governance at least remains a challenge. Given the enterprise's unwillingness to develop new corporate meanings, respond to social expectations, and accept responsibility for the crisis, Shell's actions in light of the Nigerian crisis during the 1990s reflect the ambiguities and indeterminacies of MNEs facing changes in their normative environment. Consequentially, against more positive readings considering Shell as a role model for stakeholder engagement, ${ }^{86}$ the illustration and its conclusions should be read as a word of caution to not prematurely perceive of Shell as a convinced and confident global governor. Without over-generalizing the findings, two considerations for further research follow. One is theoretical in nature and raises the question how to study MNEs in global governance while the other is practical and raises the question how to politically engage with MNEs in global governance.

First, MNEs always act rationally, except when they do not. In other words, being driven by the lose notion of profit does not imply the ability to act rationally in light of novel and complex situations. ${ }^{87}$ Shell's rhetoric in hindsight at least cannot be rationalized as the enterprise struggled to make sense of the crisis and relied on a trial-and-error approach. Studying MNEs in global governance based on the assumption of corporate rationality thus in conceptual terms features

85 Woll (2010), 153.

86 See for these positive accounts Holzer (2010) and Lambooy and Rancourt (2008).

87 In addition to the framework elaborated here, one could connect this finding to the literature of 'muddling through' and bounded rationality as introduced by Forester (1984). 
"many parallels with the neorealist view of the state as atomised, unitary and essentially rational"88: While helpful in certain contexts, the overall discussion should not be limited to this perspective only. As argued by Scherer et al. ${ }^{89}$, understanding MNEs in global governance relies on different theoretical frameworks and analytical tools of which at least some should problematize the intuition of equating corporate agency and rationality. The illustration at least indicates potential for a complementing, further-to-be-refined framework that takes serious the notion of corporate agency and studies corporate meanings from within such a non-essentializing perspective. For such a perspective, it is important to understand how MNEs make sense of global governance and how they thereby constitute themselves. In the end, "definition[s] of what it means to be a successful firm" 90 depend on interpretive frames advanced within MNEs and in society and thus should be treated as an open question to be discussed in multiple theoretical frameworks.

Second, the "debate about the range of strategic choices open to us in the present and future"91 on whether and how to integrate MNEs into global governance should also be as open as possible. This includes the governance of MNEs as well as the governing together with MNEs. In instances of the latter, MNEs should still be engaged and challenged in their uncertainty about their appropriate roles and responsibilities instead of allowing them to advance their own definitions. As John Dewey argued a long time ago, imputing only acquisitive motives to corporate actors, risks to lose the means necessary to better integrate them into larger social and political frameworks. ${ }^{92}$ In particular, considering their contingent meanings constituted through creative action, the integration of MNEs into global governance needs to be designed carefully in order to provide enough rationale for corporate participation yet at the same time exercise enough pressure to expose them to social expectations. For this, global governance needs a critical and active civil society continuously creating and sustaining, even forcing upon MNEs, moments of crises. Accompanied by an academic discourse, which sheds its optimism and thereby makes it harder for MNEs to evade social responsibilities, the role of business in global governance is open for debate, now more than ever.

\footnotetext{
88 Amoore (2000), 185.

89 Scherer (2009), 338-9.

90 Kollman (2008), 415.

91 Zeitlin (2007), 135.

92 Dewey (1922), 146.
} 


\section{References}

Abdelal, Rawi. 2015. "The multinational firm and geopolitics: Europe, Russian energy, and power." Business and Politics 17 (3): 553-576.

Amoore, Louise. 2000. “International Political Economy and the 'Contested Firm'." New Political Economy 5 (2): 189-204.

Ancona, Deborah, Thomas W. Malone, Wanda J. Orlikowski, and Peter M. Senge. 2007. "In Praise of the Incomplete Leader." Harvard Business Review 85 (2): 92-100.

Amoore, Louise. 2006. "Making the Modern Multinational." In Global Corporate Power, edited by Christopher May. Boulder, CO: Lynne Rienner Publishers, 47-64.

Avant, D. Deborah, Martha Finnemore, and Susan K. Sell. 2010. "Who Governs the Globe?" In Who Governs the Globe? edited by Deborah D. Avant, Martha Finnemore, and Susan K. Sell. Cambridge: Cambridge University Press, 1-31.

Barnett, Michael and Kathryn Sikkink. 2008. "From International Relations to Global Society." In The Oxford Handbook of International Relations, edited by Christian Reus-Smit and Duncan Snidal. Oxford: Oxford University Press, 62-83.

Beckert, Jens. 2003. "Economic Sociology and Embeddedness: How Shall We Conceptualize Economic Action?” Journal of Economic Issues 37 (3): 769-787.

Berliner, Daniel, and Aseem Prakash. 2015. "'Bluewashing' the Firm? Voluntary Regulations, Program Design, and Member Compliance with the United Nations Global Compact.” Policy Studies Journal 43 (1): 115-138.

Börzel, Tanja A. and Thomas Risse. 2010. “Governance without a state: Can it work?” Regulation \& Governance 4 (2): 113-134.

Börzel, Tanja A., and Christian R. Thauer. ed. 2013. Business and Governance in South Africa. Racing to the Top? New York: Palgrave Macmillan.

Brown, Dana L., Antje Vetterlein, and Anne Roemer-Mahler. 2010. "Theorizing Transnational Corporations as Social Actors: An Analysis of Corporate Motivations." Business and Politics 12 (1): 1-37.

Brühl, Tanja and Matthias Hofferberth. 2013. "Global Companies as Social Actors. Constructing Private Business in Global Governance." In The Handbook of Global Companies, edited by John Mikler. Chichester: Wiley-Blackwell Publishers, 351-370.

Brunsson, Nils. 1989. The Organization of Hypocrisy. Chichester, UK: John Wiley \& Sons, Inc.

Büthe, Tim. 2010. "Private Regulation in the Global Economy: A (P)Review." Business and Politics 12 (3): 1-38.

Büthe, Tim. and Walter Mattli. 2011. The New Global Rulers: The Privatization of Regulation in the World Economy. Princeton: Princeton University Press.

Coleman, James S. 1986. "Social Theory, Social Research, and a Theory of Action." The American Journal of Sociology 91 (6): 1309-1335.

Cutler, Claire A. 2008. "Problematizing Corporate Social Responsibility under Conditions of Late Capitalism and Postmodernity." In Authority in the Global Political Economy, edited by Volker Rittberger and Martin Nettesheim. Basingstoke, UK: Palgrave Macmillan, 189-217.

Cutler, Claire A., Virginia Haufler, and Tony Porter. eds. 1999. Private Authority and International Affairs. Albany: State University of New York Press.

Dashwood, Hevina S. 2012. The Rise of Global Corporate Social Responsibility. Mining and the Spread of Global Norms. Cambridge: Cambridge University Press. 
Deitelhoff, Nicole and Klaus Dieter Wolf. 2010. "Corporate Security Responsibility: Corporate Governance Contributions to Peace and Security in Zones of Conflict." In Corporate Security Responsibility? Corporate Governance Contributions to Peace and Security in Zones of Conflict, edited by Nicole Deitelhoff and Klaus Dieter Wolf. New York: Palgrave Macmillan, $1-25$.

Dewey, John. 1922. Human Nature and Conduct. An Introduction to Social Psychology. New York: Henry Holt and Company.

Dunning, John H. 1971. "The Multinational Enterprise: The Background.” In The Multinational Enterprise, edited by John H.Dunning. New York: Praeger Publishers, 15-48.

Eden, Lorraine. 1991. "Bringing the Firm Back In: Multinationals in International Political Economy." Millennium: Journal of International Studies 20 (2): 197-224.

Eden, Lorraine and Wendy Dobson. ed. 2005. Governance, Multinationals and Growth, Cheltenham, UK: Edward Elgar Publishing Ltd.

Emirbayer, Mustafa. 1997. "Manifesto for a Relational Sociology." The American Journal of Sociology 103 (2): 281-317.

Emirbayer, Mustafa and Ann Mische. 1998. "What is Agency?” The American Journal of Sociology 103 (4): 962-1023.

Farrell, Henry and Abraham L. Newman. 2015. "Structuring power: business and authority beyond the nation state." Business and Politics 17 (3): 527-552.

Finnemore, Martha. 2014. "Dynamics of Global Governance: Building on What We Know." International Studies Quarterly 58 (1): 221-224.

Flohr, Annegret, Lothar Rieth, Sandra Schwindenhammer, and Klaus Dieter Wolf. 2010. The Role of Business in Global Governance. Corporations as Norm Entrepreneurs. Basingstoke, UK: Palgrave Macmillan.

Fontrodona, Joan and Alejo Jose G. Sison. 2006. "The Nature of the Firm, Agency Theory and Shareholder Theory: A Critique from Philosophical Anthropology.” Journal of Business Ethics 66 (1): 33-42.

Forester, John. 1984. "Bounded Rationality and the Politics of Muddling Through.” Public Administration Review 44 (1): 23-31.

Franke, Ulrich and Ulrich Roos. 2010. "Actor, structure, process: transcending the state personhood debate by means of a pragmatist ontological model for International Relations theory." Review of International Studies 36 (4): 1057-1077.

Geppert, Mike. 2003. "Sensemaking and Politics in MNCs." Journal of Management Inquiry 12 (4): 312-329.

Geppert, Mike and Christopher Dörrenbächer. 2014. "Politics and Power within Multinational Corporations: Mainstream Studies, Emerging Critical Approaches and Suggestions for Future Research." International Journal of Management Reviews 16 (2): 226-244.

Gillies, Alexandra. 2010. "Reputational Concerns and the Emergence of Oil Sector Transparency as an International Norm.” International Studies Quarterly 54 (1): 103-126.

Goddard, Stacie E. and Daniel H. Nexon. 2005. "Paradigm Lost? Reassessing Theory of International Politics." European Journal of International Relations 11 (1): 9-61.

Granovetter, Mark. 1985. "Economic Action and Social Structure: The Problem of Embeddedness." The American Journal of Sociology 91 (3): 481-510.

Griffin, Jennifer J. and Aseem Prakash. 2014. "Corporate Responsibility: Initiatives and Mechanisms.” Business \& Society 53 (4): 465-482.

Hall, Rodney B. and Thomas J. Biersteker. eds. 2002. The Emergence of Private Authority in Global Governance. Cambridge: Cambridge University Press. 
Haufler, Virginia. 2001. A public role for the private sector. Industry Self-Regulation in a Global Economy. Washington, DC: Carnegie Endowment for International Peace.

Haufler, Virginia. 2010. "Corporations in zones of conflict: issues, actors, and institutions." In Who Governs the Globe? edited by Deborah D. Avant, Martha Finnemore, and Susan K. Sell. Cambridge: Cambridge University Press, 102-130.

Heidenreich, Martin. 2012. "The Social Embeddedness of Multinational Companies. A Literature Review." Socio-Economic Review 10 (3): 549-579.

Hellmann, Gunther. 2009. “The Forum: Pragmatism and International Relations.” International Studies Review 11 (3): 638-662.

Hofferberth, Matthias. 2011. "The Binding Dynamics of Non-Binding Governance Arrangements. The Voluntary Principles on Security and Human Rights and the Cases of BP and Chevron." Business and Politics 13 (4): 1-32.

Hofferberth, Matthias, Tanja Brühl, Eric Burkhart, Marco Fey, and Anne Peltner. 2011. “Multinational Enterprises as 'Social Actors'. Constructivist Explanations for Corporate Social Responsibility.” Global Society 25 (2): 205-226.

Hofferberth, Matthias and Christian Weber. 2015. "Lost in Translation: A Critique of Constructivist Norm Research." Journal of International Relations and Development 18 (1): 75-103.

Holzer, Boris. 2010. Moralizing the Corporation. Transnational Activism and Corporate Accountability. Cheltenham, UK: Edward Elgar Publishing Ltd.

Jackson, Patrick T. and Daniel H. Nexon. 2013. "International Theory in a Post-Paradigmatic Era: From Substantive Wagers to Scientific Ontologies." European Journal of International Relations 19 (3): 543-565.

Jensen, Nathan M. 2006. Nation-states and the multinational corporation: a political economy of foreign direct investment. Princeton, NJ: Princeton University Press.

Joas, Hans. 1997. The Creativity of Action. Chicago: University of Chicago Press.

Kaldor, Mary. ed. 2007. Oil Wars. London: Pluto.

Karns, Margaret P., Karen A. Mingst, and Kendall W. Stiles. 2015. International Organizations. The Politics and Processes of Global Governance, 3rd edition. Boulder, CO: Lynne Rienner Publishers.

Kinderman, Daniel. 2012. “'Free Us Up So We Can Be Responsible!' The Co-Evolution of Corporate Social Responsibility and Neo-Liberalism in the UK, 1977-2010." Socio-Economic Review 10 (1): 29-57.

Kobrin, Stephen. J. 2008. "Globalization, Transnational Corporations and the Future of Global Governance." In Handbook of Research on Global Corporate Citizenship, edited by Andreas G. Scherer and Guido Palazzo. Northampton, UK: Edward Elgar Publishing Ltd, 249-272.

Kobrin, Stephen. J. 2009. "Private Political Authority and Public Responsibility: Transnational Politics, Transnational Firms, and Human Rights.” Business Ethics Quarterly 19 (3): 349-374.

Kollman, Kelly. 2008. "The Regulatory Power of Business Norms: A Call for a New Research Agenda." International Studies Review 10 (3): 397-419.

Kostova, Tatiana, Kendall Roth, and M. Tina Dacin. 2008. "Institutional Theory in the Study of Multinational Enterprises: A Critique and New Directions." Academy of Management Review 33 (4): 994-1006.

Kristensen, Peer H. and Jonathan Zeitlin. 2005. Local Players in Global Games. The Strategic Constitution of a Multinational Corporation. Oxford: Oxford University Press.

Lambooy, Tineke and Marie-Eve Rancourt. 2008. "Shell in Nigeria. From Human Rights Abuse to Corporate Social Responsibility." Human Rights \& International Legal Discourse 2 (2): 229-275. 
Lawrence, Anne T. 2002. "The Drivers of Stakeholder Engagement. Reflections on the Case of Royal Dutch/Shell." The Journal of Corporate Citizenship 6 (1): 71-85.

Levy, David L. and Aseem Prakash. 2003. "Bargains Old and New: Multinational Corporations in Global Governance.” Business and Politics 5 (2): 131-150.

March, James G. and Johan P. Olsen. 1989. Rediscovering Institutions: The Organizational Basis of Politics. New York: Free Press.

Matten, Dirk and Andrew Crane. 2005. "Corporate Citizenship: Toward an Extended Theoretical Conceptualization.” Academy of Management Review 30 (1): 166-179.

Mattli, Walter and Ngaire Woods. 2009. The Politics of Global Regulation. Princeton, NJ: Princeton University Press.

May, Christopher. 2015. Global Corporations in Global Governance. London: Routledge.

O'Neill, Philip and J.K. Graham-Gibson. 1999. "Enterprise Discourse and Executive Talk: Stories that Destabilize the Company." Transactions of the Institute of British Geographers 24 (1): $11-22$.

Omeje, Kenneth. 2006. High Stakes and Stakeholders. Oil Conflict and Security in Nigeria. Aldershot, UK: Ashgate.

Ougaard, Morten and Anna Leander. ed. 2010. Business and Global Governance. New York: Routledge.

Palan, Ronen. 2000. “New Trends in Global Political Economy.” In Global Political Economy. Contemporary Theories, edited by Ronen Palan. London: Routledge, 1-18.

Pattberg, Philipp H. 2005. "The Institutionalization of Private Governance: How Business and Nonprofit Organizations Agree on Transnational Rules." Governance 18 (4): 589-610.

Pies, Ingo, Stefan Hielscher, and Markus Beckmann. 2009. "Moral Commitments and the Societal Role of Business: An Ordonomic Approach to Corporate Citizenship." Business Ethics Quarterly 19 (3): 375-401.

Powell, Walter W and Paul J. DiMaggio. ed. 1991. The New Institutionalism in Organizational Analysis. Chicago: University of Chicago Press.

Prakash, Aseem. 2002. "Beyond Seattle: Globalization, the Nonmarket Environment and Corporate Strategy." Review of International Political Economy 9 (3): 513-537.

Ruggie, John. G. 2004. "Reconstituting the Global Public Domain. Issues, Actors and Practices." European Journal of International Relations 10 (4): 499-531.

Sabel, Charles F. and Jonathan Zeitlin. 1997. "Stories, Strategies, Structures: Rethinking Historical Alternatives to Mass Production." In World of Possibilities. Flexibility and Mass Production in Western Industrialization, edited by Charles F. Sabel and Jonathan Zeitlin. Cambridge: Cambridge University Press, 1-33.

Sagafi-nejad, Tagi. 2008. The UN and Transnational Corporations. From Code of Conduct to Global Compact. Bloomington, IN: Indiana University Press.

Schäferhoff, Marco, Sabine Campe, and Christopher Kaan. 2009. "Transnational Public-Private Partnerships in International Relations. Making Sense of Concepts, Research Frameworks, and Results." International Studies Review 11 (3): 451-474.

Scherer, Andreas G., Guido Palazzo, and Dorothee Baumann. 2006. "Global Rules and Private Actors: Toward a New Role of the Transnational Corporation in Global Governance." Business Ethics Quarterly 16 (4): 505-532.

Scherer, Andreas G., Guido Palazzo, and Dirk Matten. 2009. "Introduction to the Special Issue: Globalization as a Challenge for Business Responsibilities." Business Ethics Quarterly 19 (3): 327-347. 
Scherer, Andreas G., Andreas Rasche, Guido Palazzo, and Andre Spicer. 2016. "Managing for Political Corporate Social Responsibility. New Challenges and Directions for PCSR 2.0." Journal of Management Studies, Accepted Article, doi: 10.1111/joms.12203.

Scott, Richard W. 2008. Institutions and Organizations. Ideas and Interests. Los Angeles: Sage Publications Ltd.

Senge, Peter M. 2006. The Fifth Discipline. The Art \& Practice of The Learning Organization, 2nd edition. New York: Currency.

Sinclair, Timothy J. 2012. Global Governance. Cambridge: Polity Press.

Sluyterman, Keetie. 2007. Keeping Competitive in Turbulent Markets, 1973-2007. A History of Royal Dutch Shell. Oxford: Oxford University Press.

Soares de Oliveira, Ricardo. 2007. Oil and Politics in the Gulf of Guinea. London: Hurst and Company.

Soule, Sarah A. 2012. "Social Movements and Markets, Industries, and Firms." Organization Studies 33 (12): 1715-1733.

Sundaram, Anant K. and Andrew C. Inkpen. 2004. "The Corporate Objective Revisited." Organization Science 15 (3): 350-363.

Weiss, Thomas G. and Rorden Wilkinson. 2014. "Global Governance to the Rescue: Saving International Relations?” Global Governance 20 (1): 19-36.

Wickert, Christopher, Andreas G. Scherer, and Laura J. Spence. 2016. "Walking and Talking Corporate Social Responsibility. Implications of Firm Size and Organizational Cost." Journal of Management Studies, Accepted Article, doi: 10.1111/joms.12209.

Whelan, Glen. 2012. "The Political Perspective of Corporate Social Responsibility: A Research Agenda." Business Ethics Quarterly 22 (4): 709-737.

Wolf, Klaus Dieter. 2008. "Emerging Patterns of Global governance: The New Interplay Between the State, Business and Civil Society." In Handbook of Research on Global Corporate Citizenship, edited by Andreas G. Scherer and Guido Palazzo. Northampton, UK: Edward Elgar Publishing Ltd, 225-248.

Woll, Cornelia. 2008. Firm Interests. How Government shape Business Lobbying on Global Trade. Ithaca, NY: Cornell University Press.

Woll, Cornelia. 2010. "Firm Interests in Uncertain Times: Business Lobbying in Multilateral Service Liberalization." In Constructing the International Economy, edited by Rawi Abdelal, Mark Blyth, and Craig Parsons. Ithaca, NY: Cornell University Press, 137-154.

Yin, Robert K. 2013. Case Study Research: Design and Methods, 5th edition. Thousand Oaks, CA: Sage Publications Ltd.

Zeitlin, Jonathan. 2007. "The Historical Alternatives Approach.” In The Oxford Handbook of Business History, edited by Geoffrey Jones and Jonathan Zeitlin. Oxford: Oxford University Press, $120-140$.

Zimmer, Melanie. 2010. "Oil Companies in Nigeria: Emerging Good Practice or Still Fueling Conflict?" In Corporate Security Responsibility? Corporate Governance Contributions to Peace and Security in Zones of Conflict, edited by Nicole Deitelhoff and Klaus Dieter Wolf. New York: Palgrave Macmillan, 58-84. 